\title{
Immunohistochemical Demonstration of Somatostatin-Containing Cells in the Human Placenta
}

\author{
Morimi Nishinira and Soroku Yagihashi \\ The First Department of Pathology, Hirosaki University School \\ of Medicine, Hirosaki 036
}

\begin{abstract}
NishuHira, M. and Yaginashi, S. Immunohistochemical Demonstration of Somatostatin-Containing Cells in the Human Placenta. Tohoku J. exp. Med., 1978, 126 (4), 397-398, — Present study using immunohistochemical methods clearly demonstrated the presence of somatostatin-containing cells in the human placenta. These cells were located in the cytotrophoblastic layer, while the layer of syncytiotrophoblasts showed no positive reaction. With the progress of gestation, these immunoreactive somatostatin-containing cells disappeared. It was suggested that somatostatin or somatostatin-like substances play an important role in the maintenance of gestation._- human placenta; somatostatin cells; gestation
\end{abstract}

The main endocrine products of the placenta are considered to closely resemble those of the pituitary gland. On the other hand, somatostatin (GIF) originally isolated from ovine hypothalamus (Brazeau et al. 1973) has been proved to be distributed in various organs, and to have an inhibitory effect on pituitary peptide hormones. Hence we began to have an impression that somatostatin has more or less responsibilities for a hormonal regulation in the human placenta.

Now we report the immunohistochemical evidence for the presence of somatostatincontaining cells and their morphological changes in various gestational periods.

\section{Materials and Methods}

Fresh human placental villi removed from 11 pregnant women of 6 to 40 weeks of gestation were fixed in Bouin's solution. Paraffin sections in $4 \mu \mathrm{m}$-thickness for the immunoperoxidase procedure were obtained by conventional methods.

Specific somatostatin antisera which were raised in our laboratory by immunization of rabbits using synthetic somatostatin (Peptide Institute Research Foundation, Osaka), coupled with human $\alpha$-globulin (Yagihashi et al., to be published), were diluted 1:25 with phosphate buffered saline and applied to specimens of placenta after deparaffinization for $1 \mathrm{hr}$ at $37^{\circ} \mathrm{C}$. After washing with the same buffer, peroxidase-labeled goat anti-rabbit IgG sera (Fuji Zoki Co., Tokyo) diluted 1:8 were applied for $40 \mathrm{~min}$. The sections were observed under the light microscope, after stained with $3,3^{\prime}$-diaminobenzidine (Nakarai Chem., Ltd., Kyoto).

Control studies were performed (a) by absorbing the specific somatostatin antisera with excess purified somatostatin, (b) by substituting preimmune serum for the specific serum and (c) by omitting the first step of the application of anti-somatostatin sera, thus staining with peroxidase alone.

\section{Resutits}

In the early gestational placenta, somatostatin-containing cells were obviously noticed

Received for publication, May 4, 1978. 
by dark-brown granular cytoplasm. Their immunoreactivity was distributed in the monolayer of cytotrophoblasts which were composed of immunoreactive cytoplasm and large non-immunoreactive central nuclei (Fig. 1). No immunoreactivity of the placental sections was recognized in control studies (Fig. 2). The intensity of immunocytological reactions of somatostatin-containing cells became reduced at the second and third trimesters. In the term placenta, there was no immunoreactivity in either layer of trophoblasts.

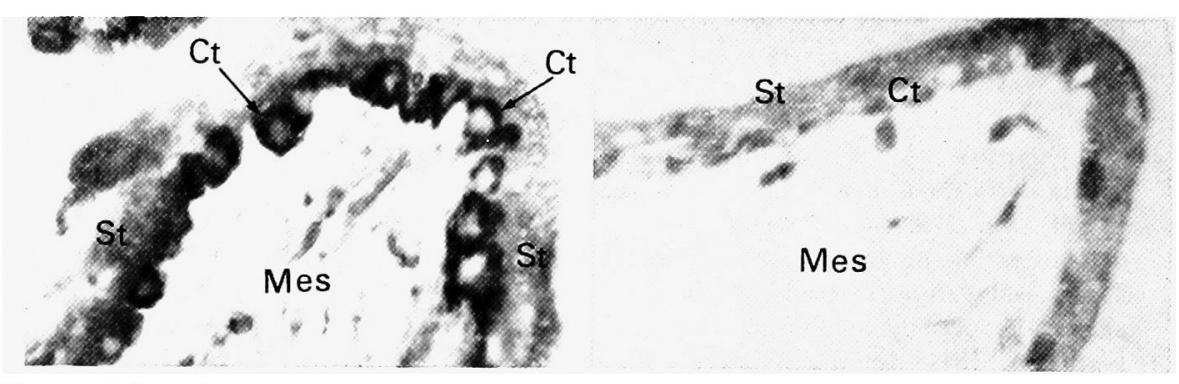

Fig. 1 (left). Immunoreactive somatostatin-containing cells (arrows) distributed in cytotrophoblasts $(\mathrm{Ct})$ of the human placenta at seven weeks of gestation. Mes, mesenchyme; St, syncytiotrophoblast. $\times 960$.

Fig. 2 (right). Control section of human placenta at seven weeks of gestation, showing no immunoreactivity. This section was pretreated with excess purified somatostatin. $\times 960$.

\section{Discussion}

The present study has shown the presence of immunoreactive somatostatin-containing cells in the human placenta and their time-dependent changes in gestation. By recent immunohistochemical studies (Mason et al. 1969; de Ikonikoff and Cedard 1973), it has been demonstrated that the placental tropic hormone-containing cells, i.e., human chorionic gonadotropin- or human chorionic somatomammotropin-containing cells are located in the syncytiotrophoblastic layer. In our study, somatostatin-containing cells were distributed in the cytotrophoblastic layer. With the progress of gestation, the intensity of immunocytological reactions became reduced, and diminished in the term placenta.

When we consider about the suppressive function of somatostatin on the tropic hormones of the pituitary gland, somatostatin in the human placenta possibly plays an important role in a hormonal regulation at various periods of gestation.

\section{Acknowledgment}

We are greatly indebted to Prof. K. Nagai and Prof. S. Shinagawa for their thoughtful directions and criticism in this study.

\section{References}

1) Brazeau, P., Vale, W., Burgus, R., Ling, N., Butcher, M., Rivier, J. \& Guillemin, R. (1973) Hypothalamic polypeptide that inhibits the secretion of immunoreactive pituitary growth hormone. Science, 179, 77-79.

2) de Ikonikoff, L.K. \& Cedard, L. (1973) Localization of human chorionic gonadotropic and somatomammotropic hormones by the peroxidase immunohistoenzymologic method in villi and amniotic epithelium of human placentas (from six weeks to term). Amer. J. Obstet. Gynec., 116, 1124-1132.

3) Mason, T.E., Phifer, R.F., Spicer, S.S., Swallow, R.A. \& Dreskin, R.B. (1969) An immunoglobulin-enzyme bridge method for localizing tissue antigens. J. Histochem. Cytochem., 17, 563-569. 